\title{
Offshoring, Immigration, and the Native Wage Distribution
}

\author{
William W. Olney ${ }^{1}$ \\ Department of Economics \\ Williams College
}

\begin{abstract}
This paper presents a simple model that examines the impact of offshoring and immigration on wages and tests these predictions using U.S. state-industry-year panel data. According to the model, the productivity effect causes offshoring to have a more positive impact on low-skilled wages than immigration, but this gap decreases with the workers' skill level. The empirical results confirm both of these predictions and thus present direct evidence of the productivity effect. Furthermore, the results provide important insight into how specific components of offshoring and immigration affect the wages of particular types of native workers.

Keywords: offshoring, outsourcing, immigration, productivity effect, wages

JEL Codes: F16, F22, J3

\footnotetext{
${ }^{1}$ Department of Economics, Williams College, Williamstown, MA 01267 (email: william.olney@williams.edu). I am grateful to Brian Cadena, Jennifer Hunt, Wolfgang Keller, Keith Maskus, Stephen Yeaple, and seminar participants at the 2009 Midwest International Trade Meetings, the 2009 Empirical Investigations in Trade and Geography, the 2010 Rocky Mountain Empirical Trade Conference, and the University of Colorado International Trade Seminar Series for helpful comments and suggestions.
} 


\section{Introduction}

Workers in developed countries are becoming increasingly concerned about the impact of offshoring and immigration on their domestic labor markets. ${ }^{2}$ Offshoring and immigration are the two factors that are of most concern to American workers: $77 \%$ of Americans think that offshoring has hurt them (13\% believe it has helped) and $55 \%$ of Americans believe immigration has hurt them (28\% believe it has helped). ${ }^{3}$ While many American workers blame their stagnant wages on the increased prevalence of offshoring and immigration, the available evidence on the link between offshoring, immigration, and wages remains mixed. In order to investigate the validity of these fears and clarify these relationships, this paper presents a model that highlights the impact of offshoring and immigration on wages and then tests these predictions using a comprehensive data set.

The offshoring of domestic jobs and the immigration of foreign workers are mechanisms that increase the effective labor force available to domestic firms. In this respect, offshoring and immigration will have a similar effect on wages. However, their impact on wages differs if the benefits associated with cross country wage differences accrue to different factors of production. Specifically, with offshoring the firm captures the rents associated with cross country wage differences but with immigration the migrant worker captures these rents.

A simple model is constructed that clarifies these relationships between the offshoring of low-skilled tasks, low-skilled immigration, and wages. Both offshoring and immigration generate a labor-supply effect which depresses the wage of low-skilled workers but increases the wage of high-skilled workers. Offshoring also generates a productivity effect which refers to the cost savings that firms enjoy after relocating some tasks abroad. The productivity effect increases the wage of low-skilled workers but has no direct effect on the wage of highskilled workers. Immigration does not generate a productivity effect since the benefits of cross country wage differences are captured by the immigrants rather than the domestic firms. Thus, comparing the impact of offshoring and immigration on the wages of native workers offers a unique opportunity to test for the presence of the productivity effect.

\footnotetext{
${ }^{2}$ Offshoring refers to the relocation of domestic jobs to foreign countries.

3 "Public Says American Work Life is Worsening, But Most Workers Remain Satisfied with Their Jobs," Pew Research Center, 2006.
} 
Specifically, due to the productivity effect, offshoring has a more positive impact on lowskilled wages than immigration (Proposition 1), but this gap decreases with the workers' skill level (Proposition 2).

The predicted impact of immigration and offshoring on the wages of different types of native workers is then tested using a comprehensive U.S. data set that includes 48 states, 14 industries, and 7 years. This data is appealing because it exploits state and industry variation over time and it includes service and manufacturing industries. The inclusion of state, industry, year, state*year, and industry*year fixed effects means that factors such as geographic differences, differences in industry productivity trends, and state macroeconomic trends will be controlled for in this analysis. The endogeneity of the offshoring and immigration decision is addressed by taking advantage of the variation in these variables that is exogenous to local demand shocks and wages. Specifically, the offshoring instrument is constructed using variation in offshoring that is driven by changes in foreign country characteristics over time. The immigration instrument is constructed by taking advantage of the fact that current immigrants often locate in areas where previous immigrants from the same country already live (Bartel 1989). This instrumental variable estimation strategy identifies the causal impact of offshoring and immigration on native wages.

The results confirm both propositions of the model. Offshoring of low-skilled tasks increases the wages of low-skilled native workers while low-skilled immigration has a slight negative effect on these wages. However, offshoring and immigration have a more similar impact on the wages of high-skilled native workers. Thus, the empirical results provide strong evidence of the productivity effect. The productivity effect is large enough to compensate for the labor supply effect and causes offshoring to actually increase the wages of low-skilled native workers. This surprising result is fully consistent with the predictions of the model.

An additional analysis examines the impact of offshoring and immigration on native wage deciles, rather than simply focusing on low-skilled and high-skilled wages. This provides a more complete picture of how these forms of globalization affect the native wage distribution. The results again confirm both predictions of the model and provide even stronger empirical support for the productivity effect. Offshoring has a more positive impact on the wages at 
the low end of the distribution than immigration, but this gap decreases as the wage deciles increase.

In addition, these results provide important insight into how specific components of offshoring and immigration affect particular types of native workers. The implications of offshoring and immigration on wages depends on the skill level of the immigrant and on the skill level of the offshored tasks, which is identified using the level of development of the foreign host country. Finally, these findings are robust to using an alternate offshoring instrument, to using a different measure of income, to changes in the sample, and to alternate specifications. ${ }^{4}$

Some recent theoretical papers have examined the impact of offshoring and immigration on native wages (Jones 2005, Grossman and Rossi-Hansberg 2008). These studies show how offshoring can lead to an increase in domestic wages and discuss the similarities and differences of immigration. This paper builds upon this literature by constructing a model that combines immigration and offshoring into a single, unified framework. In particular, a model is developed that incorporates immigration into a variation of the Grossman and Rossi-Hansberg's (2008) trade in task model. This produces specific predictions about how offshoring and immigration affect different types of native workers. Combining offshoring and immigration into a single framework also generates two testable predictions for the presence of the productivity effect. This is an important contribution since it has been difficult for researchers to test for the productivity effect due to the lack of adequate trade data. The empirical results that follow support both propositions of the model and thus provide the first direct empirical evidence of the productivity effect.

While the links between offshoring and wages (Feenstra and Hanson 1999, Slaughter 2000, Liu and Trefler 2008, Ebenstein, Harrison, McMillan, and Phillips 2009) and immigration and wages (Card 1990, Borjas 2003, Card 2005, Ottaviano and Peri 2008) have been examined extensively with results varying substantially, few studies combine offshoring and immigration into a comprehensive empirical analysis. Not only does this provide a unique opportunity to test for the productivity effect, it also allows for specific components of offshoring and immigration to be compared. Conflicting results in the literature typically

\footnotetext{
${ }^{4}$ These additional results can be found in an online technical appendix.
} 
arise from papers using different estimation strategies, unit of analyses, or data. However, this paper shows that immigration and offshoring have very different impacts on native wages depending on the skill level of immigrants and on the income level of the foreign country. This improves our understanding of how these global forces affect the wages of native workers and may reconcile some of the mixed results in the literature.

To the best of my knowledge, the only other papers that consider offshoring and immigration in a unified framework are Ottaviano, Peri, and Wright (2010) and Barba Navaretti, Bertola, and Sembenelli (2008). ${ }^{5}$ The first paper complements this analysis in that it focuses on the impact of offshoring and immigration on employment rather than on wages. The second paper examines the characteristics of Italian firms that choose to offshore but does not look at the implications of offshoring or immigration on wages. Furthermore, in contrast to this analysis which includes a wide array of industries, both of these other papers focus exclusively on the relatively small manufacturing sector.

Recent studies have provided highly publicized estimates of the number of U.S. jobs that may be offshored in the coming years (Blinder 2007, Jensen and Kletzer 2005, McKinsey Global Institute 2005). While these papers offer a rough estimate of the scope of offshoring, they do not address the implications of offshoring for native workers. Between $22 \%-29 \%$ of all U.S. jobs are potentially offshorable (Blinder 2007), but without a clear idea of how offshoring impacts domestic labor markets, interpreting these results is difficult. This paper fills this void by identifying how different components of offshoring affect particular types of native workers. The results that follow suggest that certain types of offshoring are beneficial for particular types of native workers.

The remainder of the paper is organized as follows. A simple model is constructed in the next section which highlights the impact of offshoring and immigration on wages. Section 3 describes the data used in this analysis and presents descriptive statistics while Section 4 presents the estimation strategy and describes the instrument used in the IV regressions. The results are discussed in Section 5, and Section 6 concludes.

\footnotetext{
${ }^{5}$ In addition, Hickman and Olney (2011) examine the impact of globalization on human capital investment and find that community college enrollments increase in response to offshoring and immigration.
} 


\section{Model}

Following Grossman and Rossi-Hansberg (2008), I model offshoring as trade in tasks. The productivity effect arises in an environment in which there are heterogeneous costs of offshoring tasks, while the labor-supply effect arises in an environment in which there are more factors of production than goods. Thus, in order to simply and clearly illustrate these competing effects, the model focuses on a small economy that produces a single good using two factors and that faces increasing costs of offshoring tasks. ${ }^{6}$ In addition, immigration, which leads to changes in the domestic labor supply, is included in the model. While other authors have discussed the similarities and differences of offshoring and immigration (Jones 2005, Grossman and Rossi-Hansberg 2008), this is one of the few papers that incorporates immigration into a trade in task framework. Combining offshoring and immigration in a unified model generates clear, testable predictions for the productivity effect.

Consider a small economy, such as a state, that takes the price and the foreign wage as given and specializes in the production of a particular good Y. The production of good Y requires L-workers, who are relatively less skilled, and H-workers, who are relatively more skilled. There is a continuum of L-tasks and a continuum of H-tasks performed by each type of worker. The tasks are defined such that each task must be performed once in order to produce a unit of good Y. Each L-task requires $a_{L}$ units of domestic low-skilled labor, and each H-task requires $a_{H}$ units of domestic high-skilled labor. Substitution between L-tasks and H-tasks is possible, and thus both unit requirements are chosen by the firm in order to minimize costs. Without loss of generality, the number of $\mathrm{L}$ and $\mathrm{H}$ tasks is normalized to one. Therefore, $a_{L}$ and $a_{H}$ also indicate the amount of domestic L-labor and H-labor necessary to produce a unit of good Y.

The costs associated with offshoring vary by task. This can capture a number of different factors that can make some tasks inherently more difficult to offshore than others. For

\footnotetext{
${ }^{6}$ Including a second good in the model and relaxing the small country assumption would generate, in addition to the productivity effect and labor-supply effect, a "relative-price effect" caused by offshoring. This would put downward pressure on the low-skilled wage and upward pressure on the high-skilled wage via the Stolper Samuelson Theorem (Grossman and Rossi-Hansberg 2008). While this is an interesting extension, the relative price effect is not crucial for this analysis, and thus I try to keep the model as simple as possible. If anything, the relative price effect would work against the propositions of the model and the empirical results that follow.
} 
instance, how routine or codifiable the task is, or how much face to face contact is necessary to carry out the task, or how easy it is to electronically transmit the output can all influence how costly it is to offshore a task (Blinder 2007). For the purposes of this analysis, we need to simply recognize that the costs of offshoring differ by task. The L-tasks are ordered such that the costs of offshoring are increasing and it is assumed that it is prohibitively costly to offshore H-tasks. In addition, the immigration of L-workers to the home state is possible, while the immigration of $\mathrm{H}$-workers is negligible. ${ }^{7}$

Let $w$ and $w^{*}$ be the wages of the L-workers in the home state and foreign country respectively (with $w>w^{*}$ ). A firm can produce task $j$ domestically at a cost of $w a_{L}$, or it can produce task $j$ abroad at a cost of $w^{*} a_{L} \beta g(j)$, where $\beta$ is a shift parameter that captures changes in the cost of offshoring and $g(j)$ is a continuously differentiable function with $\beta g(j) \geq 1$ for all $j$. Firms offshore tasks in order to take advantage of lower foreign wages but face increasing costs of offshoring, $g^{\prime}(j)>0$, due to the ordering of tasks. Thus, there exists a task $J$ such that the wage savings is exactly equal to the costs of offshoring, or

$$
w=\beta g(J) w^{*}
$$

If $w<\beta g(j) w^{*}$, then task $j$ is performed at home, and if $w>\beta g(j) w^{*}$, then task $j$ is performed abroad. Therefore, tasks $j \in[0, J]$, which are relatively cheap to offshore, are carried out abroad and tasks $j \in(J, 1]$, which are relatively expensive to offshore, are carried out at home. A reduction in the cost of offshoring $(d \beta<0)$ leads to an increase in the share of low-skilled tasks that are offshored $(d J>0)$.

If firms optimally choose $a_{L}, a_{H}$, and the tasks to offshore, then profit maximization implies that price equals marginal cost

$$
P=w a_{L}(.)(1-J)+w^{*} a_{L}(.) \int_{0}^{J} \beta g(j) d j+s a_{H}(.),
$$

\footnotetext{
${ }^{7}$ While these assumptions are consistent with the findings that offshoring of high-skilled jobs and highskilled immigration are relatively small, these restrictions will be relaxed in the empirical analysis that follows.
} 
where $s$ represents the high-skilled wage and $a_{L}$ and $a_{H}$ are functions of the relative average costs of the two sets of tasks. The first term on the right-hand side represents the costs paid to domestic low-skilled workers since $(1-J)$ tasks are performed at home with $a_{L}$ low-skilled labor needed for each task. The second term on the right-hand side represents the costs of hiring foreign low-skilled workers. Since the costs vary across each task, we integrate from 0 to $J$. The third term is the costs of hiring native high-skilled workers.

Substituting (1) into (2) yields the following zero-profit condition:

$$
P=\Omega(J) w a_{L}(\Omega w / s)+s a_{H}(\Omega w / s)
$$

where

$$
\Omega(J)=1-J+\left(\int_{0}^{J} g(j) d j\right) / g(J)
$$

Here the dependence of the factor intensities $a_{L}$ and $a_{H}$ on the relative average costs is explicitly stated. If $J=0$, then no tasks are offshored, $\Omega(J)=1$, and the zero-profit condition is of the standard form. Since $g^{\prime}(j)>0$, by the ordering of tasks, it can be shown that $\Omega(J)<1$ as long as $J>0$. Therefore, the costs to the firm after offshoring some tasks are less than if they chose to perform all L-tasks domestically. Finally, an increase in the share of low-skilled tasks that are offshored $(d J>0)$ leads to a decrease in firms' costs $(d \Omega(J)<0) .{ }^{8}$ Offshoring leads to a reduction in firms' costs through the extensive margin because more tasks are offshored and through the intensive margin because it is now cheaper to offshore the tasks already produced abroad.

Domestic firms reduce their costs by optimally choosing the tasks to offshore. Since offshoring is a deliberate action on the part of the firm, offshoring features prominently in the firms' profit maximizing decision in (3). In contrast, immigration is determined by factors largely exogenous to the firm, such as changes in immigration policies or foreign economic conditions. Furthermore, since domestic firms are not allowed to discriminate

\footnotetext{
$8 \frac{\partial \Omega}{\partial J}=\frac{\int_{0}^{J} g(j) d j}{g(J)^{2}} g^{\prime}(J)$ which is negative when $J>0$. Purely for notational convenience $\Omega(J)$ will be simplified to $\Omega$ below.
} 
against immigrants by paying them lower wages, an increase in immigration does not directly reduce firms' costs..$^{9}$ Thus, immigration does not affect the profit maximizing decision facing the firm in (3). Unlike offshoring, the benefits associated with country wage differences are captured by the immigrants rather than the domestic firm. However, both offshoring and immigration will have important implications for the market-clearing conditions that follow.

Each firm performs $(1-J)$ L-tasks at home and all H-tasks at home. Domestic firms hire native low-skilled workers and low-skilled immigrants to perform the $(1-J)$ L-tasks. Therefore, the market-clearing conditions are

$$
(1-J) a_{L}(\Omega w / s) Y=(1+I) N
$$

and

$$
a_{H}(\Omega w / s) Y=H
$$

where $I \in[0,1]$ is the ratio of immigrant low-skilled workers to native low-skilled workers and $N$ is the supply of native low-skilled workers. Thus, the right-hand side of (4) represents the domestic low-skilled labor supply which consists of native and immigrant workers. $H$ is the supply of native skilled workers.

Using the zero profit condition and the market clearing conditions, we can examine how an increase in offshoring or an increase in immigration affects domestic wages. Totally differentiating equation (3), assuming that $\mathrm{P}$ is the numeraire, yields

$$
\theta_{L}(\hat{w}+\hat{\Omega})+\left(1-\theta_{L}\right) \hat{s}=0
$$

where $\theta_{L}$ is low-skilled labor's share of total costs and hats represent a percent change. Differentiating the ratio of $(4)$ to $(5)$ gives $^{10}$

\footnotetext{
${ }^{9}$ As long as employers cannot fully discriminate against immigrants by paying them the prevailing wage in their source country, the cost savings under offshoring will exceed that under immigration. Furthermore, if employers can fully discriminate, then there would be no difference between offshoring and immigration which would work against the empirical findings of this paper.

${ }^{10}$ See Appendix for derivation.
} 


$$
\sigma(\hat{s}-\hat{w}-\hat{\Omega})=\frac{d J}{(1-J)}+\frac{d I}{(1+I)}
$$

where $\sigma$ is the elasticity of substitution between the set of L-tasks and the set of H-tasks.

Combining (6) and (7) yields the percent change in the wage of low-skilled workers as a function of changes in offshoring and immigration:

$$
\hat{w}=-\hat{\Omega}-\frac{\left(1-\theta_{L}\right)}{\sigma} \frac{d J}{(1-J)}-\frac{\left(1-\theta_{L}\right)}{\sigma} \frac{d I}{(1+I)} .
$$

The first term on the right-hand side of (8) is the productivity effect. As the cost of offshoring decreases $(d \beta<0)$, more tasks are offshored $(d J>0)$, and thus the cost of performing the L-tasks declines $(\hat{\Omega}<0)$. Lower costs are equivalent to an increase in productivity of low-skilled labor. Higher productivity increases the demand for low-skilled workers and raises their wage. This is analogous to technical change that benefits low-skilled labor. The second term on the right-hand side of (8) is the labor-supply effect of offshoring. As the cost of offshoring decreases $(d \beta<0)$, more L-tasks are offshored $(d J>0)$, and thus some low-skilled workers become unemployed. In order to absorb this excess supply of workers back into the labor market, the low-skilled wage declines. Together the first and second terms of equation (8) represent the impact of offshoring on the wage of low-skilled workers in this model. The third term on the right-hand side of (8) is the labor-supply effect caused by immigration. The excess supply of low-skilled workers due to immigration reduces the low-skilled wage. From equation (8), the following proposition is immediate:

Proposition 1 Due to the productivity effect, offshoring has a more positive impact on the wage of low-skilled workers than immigration.

While both offshoring and immigration generate a labor-supply effect, offshoring also generates a productivity effect that increases the wages of low-skilled workers. The productivity effect is larger when more tasks are already being done abroad $(J>0)$ because the cost savings at the intensive margin will be larger. The cost savings at the extensive margin is negligible due to the envelope theorem. The labor-supply effect is small when the share of low-skilled labor in total $\operatorname{costs}\left(\theta_{L}\right)$ is large or when H-tasks and L-tasks are good 
substitutes ( $\sigma$ is large). Thus, under these conditions, the productivity effect will exceed the labor-supply effect and offshoring will increase the wages of low-skilled workers. This generates the seemingly counterintuitive result that offshoring can benefit the factor whose tasks are being sent abroad.

Immigration, on the other hand, unambiguously decreases the wage of low-skilled labor in this model. Immigration does not generate a productivity effect because the benefits of country wage differences are captured by the immigrants rather than the domestic firm. Unlike offshoring, immigration does not generate any direct cost savings for domestic firms since they pay immigrants and native workers the same market wage.

Using (6) and (7), it is also possible to derive the percent change in the wage of highskilled workers as a function of changes in offshoring and immigration:

$$
\hat{s}=\frac{\theta_{L}}{\sigma} \frac{d J}{(1-J)}+\frac{\theta_{L}}{\sigma} \frac{d I}{(1+I)} .
$$

Here the labor-supply effect of offshoring and immigration increases the wage of high-skilled workers. As is common in a two factor model, an increase in the effective supply of lowskilled labor increases the marginal product and wage of high-skilled workers. Offshoring does not generate a productivity effect for high-skilled workers because a decrease in the costs of offshoring $(d \beta<0)$ reduces the firms' costs of performing L-tasks with no effect on the costs of performing H-tasks. In other words, there is no direct impact of offshoring on the productivity of skilled workers although offshoring can indirectly affect the skilled wage through the labor-supply effect. Comparing equations (8) and (9) establishes the following proposition:

Proposition 2 Due to the productivity effect, the impact of offshoring and immigration on wages becomes more similar as the workers' skill level increases.

The labor-supply effects generated by offshoring and immigration have a negative impact on the low-skilled wage and a positive impact on high-skilled wage. However, the productivity effect generated by offshoring only impacts the low-skilled wage since offshoring affects the costs of performing L-tasks but not H-tasks. Thus, offshoring and immigration differ in 
their impact on the low-skilled wage but have a similar impact on high-skilled wages.

The finding that the productivity effect only impacts the low-skilled wage is an interesting and important result. The reduction in costs associated with offshoring L-tasks is analogous to an increase in the productivity of low-skilled workers which, in a general equilibrium context, drives up their wage. The costs associated with performing the H-tasks is unchanged and thus offshoring does not generate a productivity effect for the skilled wage. $^{11}$

The model focuses on the offshoring of low-skilled tasks and the immigration of lowskilled workers in part because recent experience has indicated that these are particularly important components of globalization, especially in the U.S. However, the model can easily be extended to include the offshoring of high-skilled tasks and the immigration of high-skilled workers. This would not change the existing results of the model but would rather add analogous productivity and labor-supply effects generated by skilled offshoring and immigration that work in the opposite direction. Specifically, the offshoring of highskilled tasks would generate its own productivity effect that would increase the wage of high-skilled workers but have no impact on the wage of low-skilled workers. In addition, both skilled offshoring and skilled immigration would generate a labor-supply effect that would depress the high-skilled wage and increase the low-skilled wage. While not the focal point of this model, these other types of offshoring and immigration will be controlled for in the empirical analysis.

The productivity and labor-supply effects generated by offshoring are not specific to the assumptions of the model presented in this paper. They are quite general findings that arise in a wide variety of different theoretical frameworks. ${ }^{12}$ However, the model outlined in this paper is appealing because it incorporates immigration into this trade in task framework and yet simply and clearly compares the competing productivity and labor-supply effects. Fur-

\footnotetext{
${ }^{11}$ Abstracting from the model, there are certainly other plausible explanations for who captures the savings associated with offshoring. For instance, capital owners, entrepreneurs, consumers, or even skilled workers may also benefit from the cost savings generated by offshoring. However, the empirical results that follow are consistent with the predictions of the model and indicate that the productivity effect increases the wages of low-skilled workers with little impact on high-skilled wages. Additional results in the appendix suggest that these alternate hypotheses are relatively less important.

${ }^{12}$ See Grossman and Rossi-Hansberg (2008) for a discussion of the productivity effect and the labor-supply effect in many of these different environments.
} 
thermore, an especially nice aspect of this model is that it highlights a unique opportunity to test for the productivity effect by comparing the impact of offshoring and immigration on wages. Specifically, due to the productivity effect offshoring and immigration should have a different impact on the wage distributions within an industry. The remainder of the paper examines whether there is empirical evidence that wages respond to offshoring and immigration in the manner predicted by Propositions 1 and 2 .

\section{Data}

Using state, industry, and year variation, the empirical analysis that follows will test these predictions by estimating the impact of offshoring and immigration on the wages of U.S. native workers. Specifically, each state-industry labor market is characterized by the economy discussed in the model and differences across states, industries, and years are used to identify the impact of offshoring and immigration on the native wage distribution. Thus, the data set utilized in this analysis spans the 48 contiguous U.S. states, 14 NAICS industries, and 7 years $(2000-2006)$.

\subsection{Immigration and Offshoring Variables}

Census and American Community Survey data on employed individuals who earn a positive wage, are not in school, and are between the ages of 18 and 65 is obtained from the Integrated Public Use Microdata Series (IPUMS). From these individual census observations, native wage percentiles are constructed for each state-industry-year observation.

Low-skilled immigration is calculated as the share of employed individuals who are foreign born and have a high school degree or less. This is consistent with $I$ from the model. In addition, the following control variables are calculated for each observation: the share of high-skilled immigrants, the share of native employees that are male, the share of native employees that are of a particular race and marital status, and the average age and average educational attainment of native workers.

Data on offshoring, defined as the number of employees at majority-owned foreign affil- 
iates of U.S. firms, is obtained from the U.S. Bureau of Economic Analysis (BEA). ${ }^{13}$ Given the trade in task model, focusing on foreign affiliate employment is preferable to other measures of foreign direct investment such as affiliate sales. The BEA provides foreign affiliate employment data by year, industry, and country of the foreign affiliate.

The empirical analysis focuses on the offshoring of low-skilled tasks to less-developed countries. ${ }^{14}$ This is consistent with the model in two important ways. First, offshoring to less-developed countries typically entails relocating particular production tasks abroad in order to take advantage of low foreign wages. This vertical offshoring is exactly the type of offshoring modeled in the trade in task framework. In contrast, offshoring to developed countries typically entails relocating the entire production process abroad in order to avoid transport costs. Second, offshoring to less-developed countries typically, although not always, entails the offshoring of low-skilled tasks. This is consistent with the assumption of the model that the offshoring of L-tasks is possible while the offshoring of H-tasks is prohibitively expensive. Thus, offshoring to less-developed countries is most consistent with the type of offshoring envisioned in the model.

Since offshoring data is not available by state, foreign affiliate employment (FAE) is distributed across states based on the share of state GDP to national GDP in that industry. Given the potential correlation between GDP and wages, the pre-sample 1999 GDP shares are used to construct the offshoring measure. Finally, the share of foreign affiliate employment to total employment, including both domestic and foreign employment, is calculated by state, industry, and year. Thus, offshoring is defined as the following share

\footnotetext{
${ }^{13}$ While the model does not draw a distinction between offshoring tasks to foreign affiliates or foreign armslength suppliers, the empirical section of this paper will focus on the offshoring of jobs to foreign affiliates due to data constraints. Constructing a proxy of offshoring that includes arms-length suppliers (Feenstra and Hanson 1999) is only possible in the manufacturing sector which would severly limit the sample. Since offshoring to arms-length suppliers is difficult to measure, and given that offshoring to foreign affiliates is relatively less labor intensive (Antras 2003), this definition represents a lower bound on the total amount of offshoring.

${ }^{14}$ The BEA does not provide information on the skill level of foreign affiliate employees. Thus, low-skilled offshoring is measured using foreign affiliate employment in less-developed countries. This is calculated as the difference between total foreign affiliate employment and foreign affiliate employment in Europe, Canada, Australia, and Japan.
} 


$$
L_{-} o f f_{\text {sit }}=\frac{\left[\frac{G D P_{\text {si1999 }}}{\sum_{s} G D P_{\text {si1999 }}} * F A E_{-} \text {lessdev }_{i t}\right]}{\text { Domestic_Empl }_{\text {sit }}+\left[\frac{G D P_{\text {si1999 }}}{\sum_{s} G D P_{s i 1999}} * F A E_{i t}\right]} * 100
$$

where $s$ indexes states, $i$ indicates industries, and $t$ references years. This measure of offshoring is consistent with $J$ from the model which captures the share of L-tasks that are offshored. Offshoring to developed countries and inshoring, defined as the number of employees at majority-owned U.S. affiliates of foreign firms, were constructed in an analogous manner and will be important control variables. Comparing total offshoring to data from the Trade Adjustment Assistance (TAA) program indicates that this method of distributing foreign affiliate employment across states is accurate. ${ }^{15}$

\subsection{Appealing Aspects of the Data}

Despite the limitations of the BEA data, this data set has a number of appealing features. First, using U.S. state level data is preferable to a cross country analysis where it is difficult to control for unobserved factors. Since U.S. states share similar laws, institutions, and cultural characteristics, using states as the unit of analysis limits these confounding factors. Together with the variation in offshoring and immigration across states, this means that the link between these forms of globalization and wages is more easily identified. In addition, state level data mitigates many of the mobility concerns associated with a city or county level study. Thus, states more closely resemble a closed labor market while still offering a substantial amount of variation.

Second, this analysis incorporates 14 2-digit NAICS industries which range from manufacturing to professional services to finance. ${ }^{16}$ Due to data constraints, many previous studies focus just on manufacturing industries (Feenstra and Hanson 1999, Harrison and McMillan 2006, Amiti and Wei 2009, Ottaviano et al. 2010). However, manufacturing rep-

\footnotetext{
${ }^{15}$ The TAA program has data on the number of domestic workers who are displaced due to import competition. While these variables measure slightly different things, the correlation coefficient between these two variables is 0.8 .

${ }^{16}$ Available BEA data on foreign affiliate employment restricts the analysis to these 14 industries. More disaggregated foreign affiliate employment data by industry-country-year has many more missing values due to confidentiality concerns. "Agriculture" and "mining" were combined and "professional services" and "management" were combined due to a lack of census observations by state in these industries.
} 
resents only $13 \%$ of total U.S. GDP in 2008. ${ }^{17}$ Unlike these previous studies which study a small component of the U.S. economy, this analysis examines how offshoring and immigration affect wages in a wide variety of industries. Furthermore, by focusing on highly aggregated NAICS industries and a relatively short time period, mobility across industries is less problematic. In addition, any potential bias associated with mobility across industries or states would attenuate the results.

Finally, the years included in this analysis span exogenous shocks to both offshoring and immigration caused by China joining the World Trade Organization in 2001 and changes to immigration policy following $9 / 11$.

\subsection{Descriptive Statistics}

Figure 1 plots average immigration and offshoring by state. Not surprisingly, the urban coastal states of California, New York, and New Jersey have high shares of both, Florida and Nevada have high shares of immigration, midwestern rust-belt states such as Michigan and Indiana have a high shares of offshoring, and rural isolated states such as Montana and North Dakota have low shares of both. This variation in offshoring and immigration is consistent with anecdotal evidence and provides additional confirmation that the allocation of foreign affiliate employment across states is accurate.

Figure 2 plots average immigration and offshoring by industry. Not surprisingly, there is a lot of offshoring in manufacturing but relatively little in construction, real estate, and health care. There are high immigrant shares in accommodations, administration, and agriculture while utilities, finance, and information have relatively little immigration. The substantial variation in wages, immigration, and offshoring across states and industries supports the assertion that a state-industry labor market is reasonably closed. Although the fixed effects will capture much of the variation in Figures 1 and 2, these figures provide insight into the dimensions and nature of the data set used in this analysis.

To gain a sense of the variation exploited in this analysis, I need to eliminate the variation that will be captured by the various fixed effects. This is done by first regressing the median native wage, offshoring, and immigration variables on year, state, industry, state*year, and

\footnotetext{
${ }^{17}$ Gross Domestic Product by Industry Accounts (BEA).
} 
industry*year fixed effects. The residuals from these regressions will be the variation left after accounting for the fixed effects which is the focus of this analysis. The median wage residuals and offshoring residuals are plotted in Figure 3 while the median wage residuals and immigration residuals are plotted in Figure 4. It is evident in Figure 3 that offshoring is associated with a higher median native wage. However, there is little relationship between immigration and the median native wage in Figure 4. These basic scatter plots suggest that there is an important difference between the impact of offshoring and immigration on native wages. However, to more accurately test the propositions of the model, it is necessary to examine the causal impact of low-skilled offshoring and low-skilled immigration on the wages of different types of native workers.

\section{Estimation Strategy}

\subsection{Specification}

To test the propositions of the model, the empirical analysis examines the key relationships of the model specified in equations (8) and (9). Specifically, the impact of offshoring and immigration on low-skilled wages is estimated by adding an error term, $\epsilon_{s i t}$, to (8). The error term captures unobserved factors not explicitly included in the model that may influence wages. This generates the following estimation equation

$$
L_{-} \text {wage }_{\text {sit }}=\alpha_{0}+\alpha_{1} L \_O f f_{\text {sit }}+\alpha_{2} L_{-} I m g_{\text {sit }}+\epsilon_{\text {sit }},
$$

where $s$ indexes states, $i$ indexes industries, $t$ indexes years, and $L_{-}$wage is the ln of the 25 th percentile native wage. $L \_O f f$ is offshoring of low-skilled tasks and will capture the productivity and labor-supply effects generated by offshoring (the first two terms on the right hand side of (8)). L_img is low-skilled immigration and will capture the labor-supply effect generated by immigration (the third term on the right hand side of (8)). It is assumed that $\epsilon_{\text {sit }}$ takes the following form

$$
\epsilon_{s i t}=\alpha_{3}^{\prime} X_{s i t}+\delta_{s}+\eta_{i}+\gamma_{t}+\psi_{s t}+\nu_{i t}+\varepsilon_{s i t},
$$


where $X$ is a set of control variables, $\delta_{s}$ are state fixed effects, $\eta_{i}$ are industry fixed effects, $\gamma_{t}$ are year fixed effects, $\psi_{s t}$ are state*year fixed effects, $\nu_{i t}$ are industry*year fixed effects, and $\varepsilon_{s i t}$ is measurement error. The $X$ matrix includes other globalization variables, such as offshoring to developed countries, high-skilled immigration, and inshoring, as well as demographic controls of the native population. The inclusion of state, industry, and year fixed effects means that factors such as geographic differences, differences in industry productivities, and macroeconomic factors will be controlled for in this analysis. The state*year and industry*year fixed effects will capture trends such as growth in states over time and changes in industry productivity over time which may be correlated with wages, immigration, and offshoring. ${ }^{18}$

Applying a similar transformation to (9) generates the two key estimation equations:

$$
L \_w a g e_{s i t}=\alpha_{0}+\alpha_{1} L \_O f f_{s i t}+\alpha_{2} L_{-} I_{m g} g_{s i t}+\alpha_{3}^{\prime} X_{s i t}+\delta_{s}+\eta_{i}+\gamma_{t}+\psi_{s t}+\nu_{i t}+\varepsilon_{s i t},
$$

$$
H_{\_} w_{a g} e_{s i t}=\rho_{0}+\rho_{1} L \_O f f_{s i t}+\rho_{2} L_{-} I m g_{s i t}+\rho_{3}^{\prime} X_{s i t}+\delta_{s}+\eta_{i}+\gamma_{t}+\psi_{s t}+\nu_{i t}+\varepsilon_{s i t},
$$

where $H_{\text {_wage }}$ is the $\mathrm{ln}$ of the 75 th percentile native wage. Proposition 1 of the model predicts that $\alpha_{1}>\alpha_{2}$ while Proposition 2 of the model predicts that $\rho_{1}=\rho_{2}$.

While consistent with the model, estimating the impact of offshoring and immigration on the 25 th and 75 th wage percentiles may miss important implications for other parts of the native wage distribution. To gain greater insight into the impact on the entire wage distribution, the effect of offshoring and immigration on different wage deciles of native workers is examined. Furthermore, this is especially useful in testing Proposition 2 of the model. Thus, the following equation will be estimated:

\footnotetext{
${ }^{18}$ Unfortunately, there is not enough annual variation to include state*industry, state*year, and industry*year fixed effects.
} 


$$
\text { wage }_{\text {sitd }}=\alpha_{0}+\alpha_{1} L_{-} O f f_{s i t}+\alpha_{2} L_{-} I m g_{s i t}+\alpha_{3}^{\prime} X_{s i t}+\delta_{s}+\eta_{i}+\gamma_{t}+\psi_{s t}+\nu_{i t}+\varepsilon_{s i t d} \text {. }
$$

where $d$ indexes native wage deciles. Separate regressions are run for each native wage decile. The model predicts that due to the productivity effect $\alpha_{1}>\alpha_{2}$ for low wage deciles but as the native wage deciles increase the productivity effect diminishes and thus the difference between $\alpha_{1}$ and $\alpha_{2}$ decreases. ${ }^{19}$

\subsection{Instruments}

The inclusion of a wide range of control variables and numerous fixed effects limits the endogeneity problem. However, a remaining potential issue is that an industry-state specific labor demand shock may be correlated with wages, immigration, and offshoring. For instance, an increase in the productivity of low-skilled workers could increase the demand for these workers and drive up their wage, which may encourage immigration and provide an incentive to offshore. To address these endogeneity concerns, this paper constructs instruments for the offshoring and immigration variables. Essentially these instruments use the variation in offshoring and immigration that is driven by factors in foreign countries which is exogenous to local demand shocks and wages.

The offshoring instrument is constructed by first regressing the foreign affiliate employment data on industry-year and country-year fixed effects. ${ }^{20}$ The country-year coefficients are then used to construct the instrument while the industry-year coefficients are discarded. The concern is that the industry-year variation may be driven in part by local demand shocks that could be correlated with wages. In contrast, the country-year variation is driven by changes in foreign country characteristics over time. Percent changes in the country-year coefficients are then multiplied by the pre-sample 1999 level of offshoring across industries in each country. This generates a predicted measure of U.S. offshoring that is driven by

\footnotetext{
${ }^{19}$ Quantile regressions are not used because the goal of this analysis is to examine the impact of offshoring and immigration on the overall wage distribution not on the wage distribution conditional on the control variables (essentially the distribution of the error term). Furthermore, the different levels of aggregation between wages, which would need to be at the individual level, and the globalization variables, which are at the state-industry level, make quantile regressions impossible.

${ }^{20}$ Ottaviano, Peri, and Wright (2010) use a similar method to calculate their "imputed offshoring" measure.
} 
changes in the foreign country and that is independent of domestic factors. Finally, the predicted measure of foreign affiliate employment is aggregated and attributed to states based on the methodology discussed in section 3.1.

The immigration instrument takes advantage of the fact that immigrants often settle in areas where previous immigrants from the same country already live (Bartel 1989). ${ }^{21}$ Specifically, the instrument is constructed by assigning actual immigrants in the current year to state-industries where immigrants from the same region of the world were located in the initial year. ${ }^{22}$ The sum of immigrants across the regions is then divided by total employment to get the predicted immigrant share for each skill group. This instrument captures variation in immigration that is due to factors in the foreign country that influence the total number of immigrants and which will affect states and industries differently depending on the initial distribution of immigrants. Thus, the variation in immigration that is driven by labor demand factors and that may be endogenous to wages is eliminated.

To be valid, these offshoring and immigration instruments need to be correlated with the potentially endogenous variables and uncorrelated with the error term, $\varepsilon$, in the second stage. While the former condition is easily tested using the first stage F-stat of the instruments, the latter is not since the over-identification test is not possible given that the number of instruments equals the number of endogenous variables. However, it is likely that the exclusion restriction is satisfied since variation in offshoring and immigration that is driven by changes in foreign country characteristics is unlikely to be correlated with unobserved factors at the industry-state level that affect wages. This is even more plausible given the inclusion of the state, industry, year, state*year, and industry*year fixed effects.

\footnotetext{
${ }^{21}$ This instrument is similar to the one used by Card (2001), Cortes (2008), and Peri and Sparber (2009). Ottaviano, Peri, and Wright (2010) construct a similar "imputed immigration" measure that uses differences in the presence of immigrant groups across industries.

${ }^{22}$ The eight regions of the world are U.S. Areas, Canada, Central America, South America, Europe, Asia, Africa, and Oceania.
} 


\section{Results}

\subsection{Low-Skilled and High-Skilled Wages}

The OLS results of estimating (10) and (11) are reported in the first two columns of Table 1. All regressions are weighted by the sample size, include the full set of fixed effects, and have robust standard errors in brackets. The results are interesting and provide preliminary support for the predictions of the model. Low-skilled offshoring has a more positive impact on the low-skilled native wage than on the high-skilled native wage. Specifically, a one percentage point increase in the share of offshoring increases the low-skilled wage $4.4 \%$ and increases the high-skilled wage by $1.0 \%$. Low-skilled immigration has a slight negative impact on both the low-skilled and high-skilled wage.

The coefficients on these two key variables of interest are consistent with the predictions of the model. Offshoring has a more positive impact on low-skilled wages than immigration which supports Proposition 1 of the model. However, offshoring and immigration have a relatively similar impact on high-skilled wages which supports Proposition 2 of the model. Furthermore, the magnitude and sign of the coefficients indicate that the productivity is important but that the labor-supply effect is small.

Columns three and four in Table 1 report the IV results from estimating (10) and (11). The IV results indicate that a one percentage point increase in offshoring increases the low-skilled wage $4.8 \%$ while a one percentage point increase in immigration decreases the low-skilled wage $0.2 \%$. A one percentage point increase in offshoring increases the high-skilled wage $1.6 \%$ while a one percentage point increase in immigration decreases the high-skilled wage $0.1 \%$. Again, offshoring has a more positive impact on low-skilled wages than immigration but this gap decreases with the workers' skill level. The productivity effect is empirically important at the low end of the wage distribution but as it dissipates the impact of offshoring and immigration on wages becomes more similar.

While not the focal point of this analysis, the coefficients on the other globalization measures are interesting. Offshoring to developed countries is measured by the $H_{-}$Offshoring variable and typically entails replicating the production process abroad in order to access foreign markets and save on transport costs. Since foreign workers are substituting for 
domestic workers it is not surprising that $H_{-}$Offshoring depresses native wages in the IV regressions in Table 1. We also see that high-skilled immigration has a slight negative impact on the wages of high-skilled native workers. Not surprisingly inshoring increases native wages.

Comparing the OLS and IV results in Table 1 indicates that the OLS coefficients on L_Offshoring are biased down while the coefficients on $L \_$Immigration, H_Offshoring, and $H_{-}$Immigration are biased up. This suggest that a positive local demand or productivity shock, which increases wages, decreases offshoring to less developed countries but increases offshoring to developed countries. The positive bias in the immigration coefficients indicates that immigrants, particularly relatively mobile high-skilled immigrants, are attracted to high wage states and industries. While there is some evidence of endogeneity bias in the OLS regressions, overall the main findings in both the OLS and IV results are consistent with the propositions of the model.

Table 2 reports the first stage IV results. Each of the four instruments have a strong impact on the globalization variable it was designed to predict. All of these coefficients are positive and significant at the one percent level. The first stage F-stat on the excluded instruments is above 63 in all regressions.

\subsection{Wage Deciles}

To gain greater insight into how offshoring and immigration affect the native wage distribution, equation (12) is estimated. Specifically, separate regressions are run using each native wage decile as the dependent variable. The OLS results are reported in Table $3{ }^{23}$

Again the results support both propositions of the model. L_Offshoring has a more positive impact on low-skilled native wages than $L_{-}$Immigration but this difference decreases as the wage deciles increase. Specifically, the second proposition of the model, that the impact of offshoring and immigration on wages becomes more similar as the workers skill level increases, is verified at multiple points in the native wage distribution. The more

\footnotetext{
${ }^{23}$ Unfortunately, the Census replaces wage values above $\$ 200,000$ with the state average of these wage values regardless of industry. While it is important to include these 'top coded' observations in order to maintain an accurate wage distribution, regressions using the 90th wage decile as the independent variable are biased and are therefore not reported.
} 
comprehensive wage decile analysis provides even more compelling evidence in support of the propositions of the model.

The results in Table 3 also indicate that the components of offshoring and immigration have very different impacts on native wages. L_Offshoring increases the wages of many native workers, particularly at the low end of the distribution, while $H_{-}$Offshoring decreases the wages of many native workers. However, $L_{-}$Immigration decreases the wages of native workers while $H_{-}$Immigration increases the wages of native workers. These contrasting results highlight the importance of controlling for the immigrant skill level and skill level of offshored tasks using the level of development of the foreign country.

In addition to differences between the independent variables, there are also important differences in how offshoring and immigration impact various types of native workers. An appealing aspect of using native wage deciles is the ability to examine how offshoring and immigration affect wage inequality. The results in Table 3 indicate that L_Offshoring decreases wage inequality since the wages at the low end of the distribution increase by relatively more than the wages at the high end. However, $H_{-}$Offshoring increases wage inequality. In contrast, immigration does not have a significant effect on wage inequality. Table 3 indicates that both types of immigration have a relatively constant effect on the wages of different types of native workers.

Table 4 reports the IV wage decile results. The IV analysis is appealing because it identifies a causal impact of offshoring and immigration on native wages by exploiting the variation in offshoring and immigration that is exogenous to local demand and wage conditions. The coefficients imply that, for instance, a one percentage point increase in lowskilled offshoring increases the median wage $3.5 \%$, while a one percentage point increase in low-skilled immigration decreases the median wage $0.2 \%$. Overall, the results in Table 4 provide even stronger support for Proposition 1 and Proposition 2 of the model. Offshoring generates a productivity effect that more than compensates for the labor supply effect at the low end of the wage distribution. However, as the wage deciles increase, the productivity effect diminishes, and thus the impact that offshoring and immigration have on native wages converges.

The L_Offshoring and L_Immigration coefficients and their $95 \%$ confidence intervals 
from Table 4 are plotted in Figure 5. The figure shows that offshoring has a more positive impact on the wages of low-skilled native workers than immigration (consistent with Proposition 1 of the model), but this gap decreases as the wage deciles increase (consistent with Proposition 2 of the model). According to the model, low-skilled immigration generates only a labor-supply effect that depresses the wages of low-skilled workers and increases the wages of high-skilled workers. The L_Immigration coefficients suggest that the laborsupply effect is relatively small. In contrast, the productivity effect, which is represented by the vertical distance between the two lines in Figures 5, is relatively large particularly at the low end of the distribution where the model predicts it should be strongest.

One potential concern is that the offshoring of low-skilled tasks and low-skilled immigration may simply displace the least skilled, lowest wage decile native workers. As these low-skilled native workers become unemployed, each wage decile would then capture a slightly more educated, higher paid native worker. However, the inclusion of the average education attainment of the native population variable, which proved to be an important control, will account for these types of compositional shifts in employment. Furthermore, if this compositional shift in employment was driving these results, one would observe offshoring and immigration leading to an initial increase in all the native wage deciles. ${ }^{24}$ The fact that neither the L_Offshoring nor the L_Immigration coefficients exhibit these patterns indicates that there is little empirical support for this hypothesis.

In contrast, the model predicts that offshoring and immigration will displace low-skilled native workers and depress their wages via the labor-supply effect. Thus, the model is fully consistent with this displacement hypothesis but the implications for native wages are quite different. The fact that the empirical results provide support for this labor-supply effect and not for the composition shift in employment story further strengthens the arguments presented in this paper.

\footnotetext{
${ }^{24}$ Given the exponential distribution of wages, it is likely that the higher wage deciles would increase by more than the lower wage deciles.
} 


\section{Conclusion}

Workers have become increasingly concerned about the impact that offshoring and immigration have on wages. Despite extensive research, which generally focuses on one or the other of these phenomena, the available evidence on the link between offshoring, immigration, and wages remains mixed. This paper presents a simple model that identifies the ways in which offshoring and immigration can affect wages. Both offshoring and immigration generate a labor-supply effect, while offshoring also generates a productivity effect that benefits low-skilled native workers. Thus, comparing the impact of offshoring and immigration on native wages offers a unique opportunity to test for the productivity effect.

The empirical results confirm that offshoring and immigration have different impacts on native wages and highlight the importance of the productivity effect. Consistent with the propositions of the model, offshoring has a more positive impact on low-skilled native wages than immigration, but this difference decreases as the wage deciles increase. These results provide direct empirical evidence that offshoring generates a productivity effect that benefits the factor whose jobs are sent abroad. More generally the empirical results presented in this paper improve our understanding of how offshoring and immigration affect native wages. The findings move us past simply thinking about whether offshoring and immigration are good or bad for the domestic economy, and instead identifies how specific components of offshoring and immigration affect particular types of native workers.

Overall, this paper shows that the impact of these important types of globalization on wages is not as bad as many American workers fear. Specifically, the offshoring of low-skilled tasks to less-developed countries complements domestic workers, generates a productivity enhancing effect, and increases low-skilled native wages. However, there is evidence that certain components of offshoring and immigration can depress the wages of specific types of native workers. Policy makers need to recognize these differences and take a

more nuanced approach to offshoring and immigration. Obviously the impact of offshoring and immigration on other dimensions of the home and foreign economies are important and warrant further research. 


\section{References}

Amiti, Mary and Shang-Jin Wei (2009) "Service Offshoring and Productivity: Evidence from the US," World Economy, 32(2): 203-20

Antràs, Pol (2003) "Firms, Contracts, and Trade Structure," Quarterly Journal of Economics, 118(4): 1375-418

Barba Navaretti, Giorgio, Giuseppe Bertola, and Alessandro Sembenelli (2008) "Offshoring and Immigrant Employment: Firm-level Theory and Evidence," Discussion Paper No. 6743, Center for Economic Policy Research

Bartel, Ann P. (1989) "Where Do the New U.S. Immigrants Live?" Journal of Labor Economics, 7(4): 371-91

Blinder, Alan S. (2007) "How Many U.S. Jobs Might Be Offshorable?" Working Paper No. 142, Center for Economic Policy Studies

Borjas, George J. (1995) "Assimilation and Changes in Cohort Quality Revisited: What Happened to Immigrant Earnings in the 1980s?" Journal of Labor Economics, 13(2): $201-45$

Borjas, George J. (2003) "The Labor Demand Curve is Downward Sloping: Reexamining the Impacts of Immigration on the Labor Market," Quarterly Journal of Economics, 118(4): 1335-74

Card, David (1990) "The Impact of the Mariel Boatlift on the Miami Labor Market," Industrial and Labor Relations Review, 43(2): 245-57

Card, David (2001) "Immigrant Inflows, Native Outflows, and the Local Market Impacts of Higher Immigration," Journal of Labor Economics, 19(1): 22-64

Card, David (2005) "Is the New Immigration Really so Bad?" The Economic Journal, 115(507): F300-23

Cortes, Patricia (2008) "The Effect of Low-Skilled Immigration on U.S. Prices: Evidence from CPI Data," Journal of Political Economy, 116(3): 381-422 
Ebenstein, Avraham, Ann Harrison, Margaret McMillan, and Shannon Phillips (2009) "Estimating the Impact of Trade and Offshoring on American Workers Using the Current Population Surveys," Working Paper No. 15107, National Bureau of Economic Research

Feenstra, Robert C. and Gordon H. Hanson (1999) "The Impact of Outsourcing and HighTechnology Capital on Wages: Estimates for the United States, 1979-1990," The Quarterly Journal of Economics, 114(3): 907-40

Feenstra, Robert C. (2007) "Globalization and Its Impact on Labor," Working Paper No. 44, Vienna Institute for International Economic Studies

Grossman, Gene M. and Esteban Rossi-Hansberg (2008) "Trading Tasks: A Simple Theory of Offshoring," American Economic Review, 98(5): 1978-97

Hanson, Gordon H., Kenneth F. Sheve, Matthew J. Slaughter, and Antonio Spilimbergo (2002) "Immigration and the U.S. Economy: Labor-Market Impacts, Illegal Entry, and Policy Choices." In Immigration Policy and the Welfare System, ed. Tito Boeri, Gordon Hanson, and Barry McCormick, 169-279 Oxford University Press

Harrison, Ann E. and Margaret S. McMillan (2008) "Offshoring Jobs? Multinationals and U.S. Manufacturing Employment," Working Paper, National Bureau of Economic Research

Hickman, Daniel C. and William W. Olney (2011) "Globalization and Investment in Human Capital," Industrial and Labor Relations Review, 64(4): 652-670

Jensen, J. Bradford and Lori G. Kletzer (2005) "Tradable Services: Understanding the Scope and Impact of Service Offshoring," In Brookings Trade Forum: 2005, ed. Susan M. Collins and Lael Brainard

Jones, Ronald W. (2005) "Immigration vs. Outsourcing: Effects on Labor Markets," International Review of Economics 8 Finance, 14(2): 105-14

Liu, Runjuan and Daniel Trefler (2008) "Much Ado About Nothing: American Jobs and the Rise of Service Outsourcing to China and India," Working Paper No. 14061, National Bureau of Economic Research 
McKinsey Global Institute (2005) The Emerging Global Labor Market.

Ottaviano, Gianmarco I.P. and Giovanni Peri (2008) "Immigration and National Wages: Clarifying the Theory and Empirics," Working Paper No. 14188, National Bureau of Economic Research

Ottaviano, Gianmarco I.P., Giovanni Peri, and Greg C. Wright (2010) "Immigration, Offshoring, and American Jobs," Working Paper No. 16439, National Bureau of Economic Research

Peri, Giovanni and Chad Sparber (2009) "Task Specialization, Immigration, and Wage,." American Economic Journal: Applied Economics, 1(3): 135-169.

Ruggles, Steven, J. Trent Alexander, Katie Genadek, Ronald Goeken, Matthew B. Schroeder, and Matthew Sobek. Integrated Public Use Microdata Series: Version 5.0 [Machine-readable database]. Minneapolis: University of Minnesota, 2010

Slaughter, Matthew J. (2000) "Production Transfer within Multinational Enterprises and American Wages," Journal of International Economics, 50(2): 449-72 
FIGURE 1

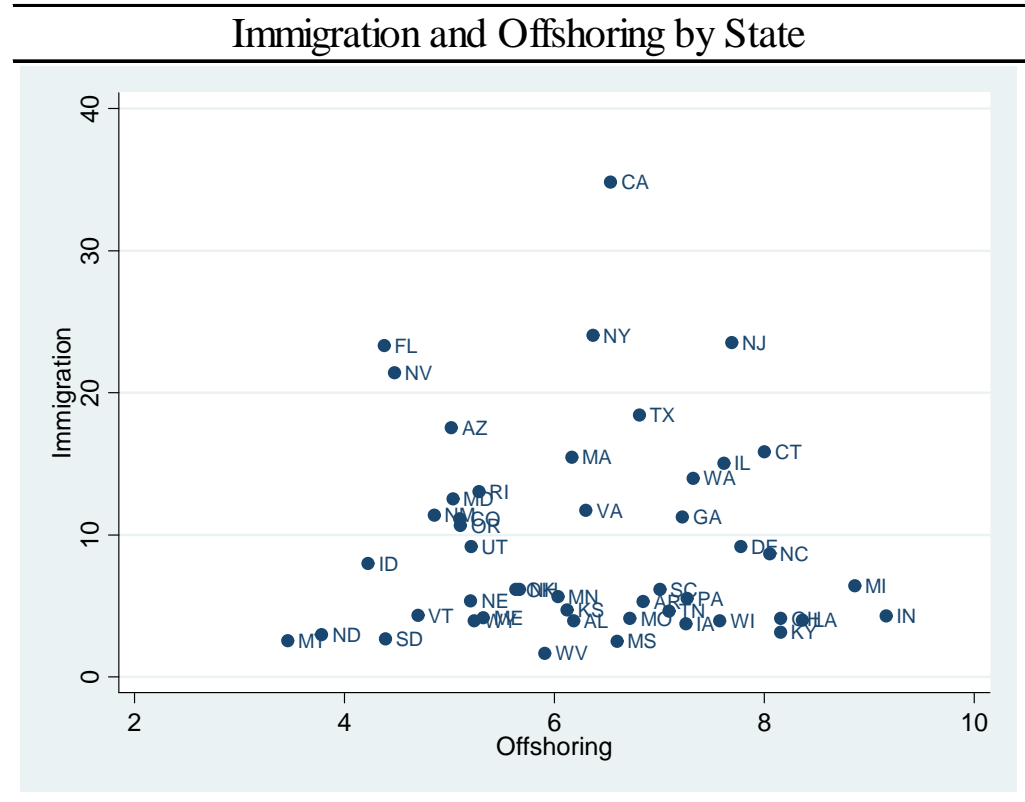

State average of the share of employees that are foreign born and the share of employees that work abroad weighted by the sample size.

FIGURE 2

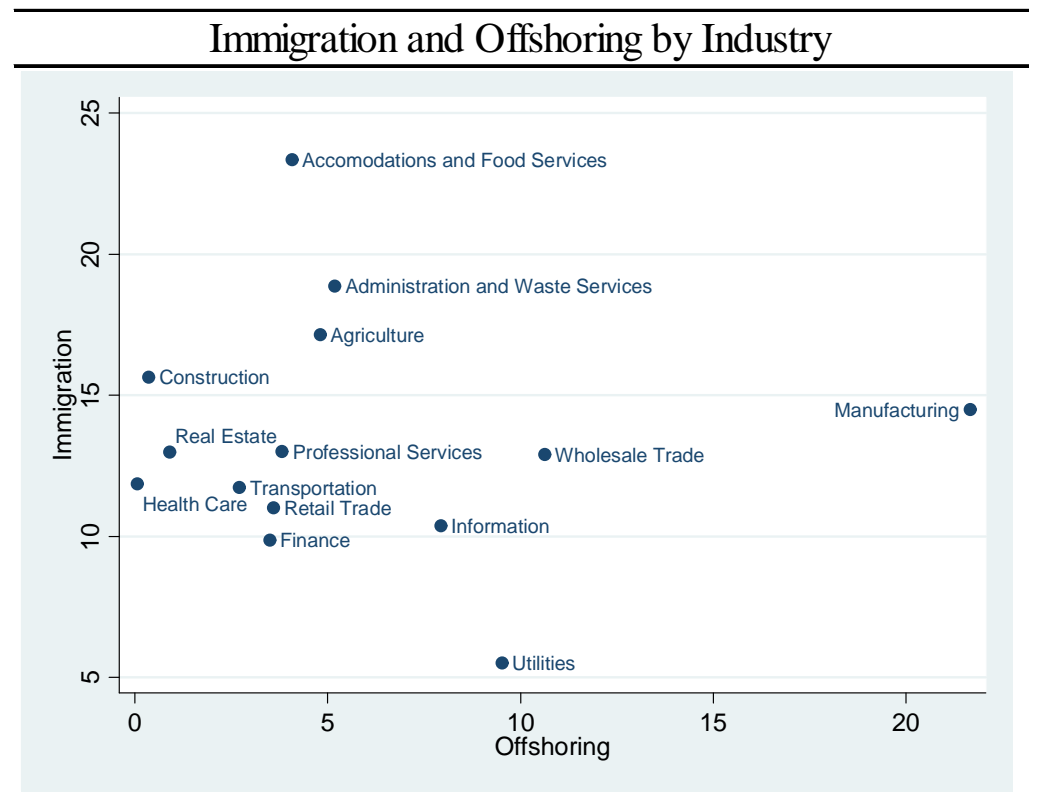

Industry average of the share of employees that are foreign born and the share of employees that work abroad weighted by the sample size. 
FIGURE 3

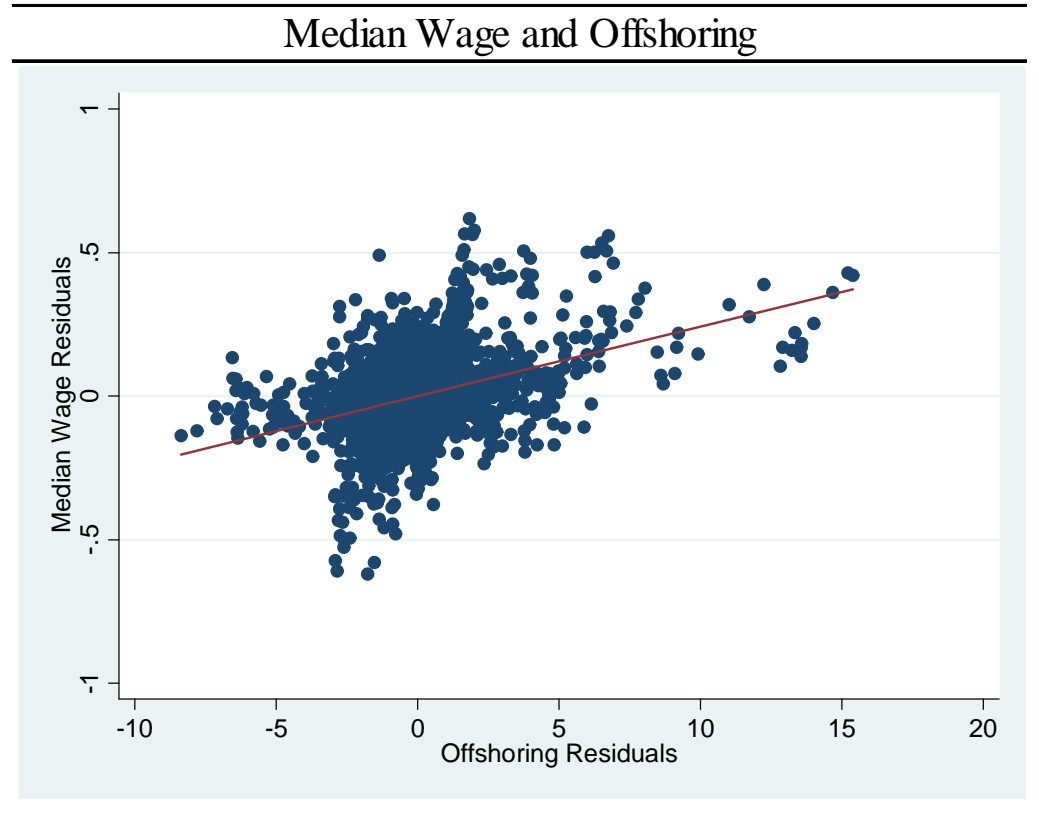

The residuals from regressing the ln native median wage on state, industry, and year fixed effects are plotted against the residuals from regressing offshoring on state, industry, and year fixed effects.

FIGURE 4

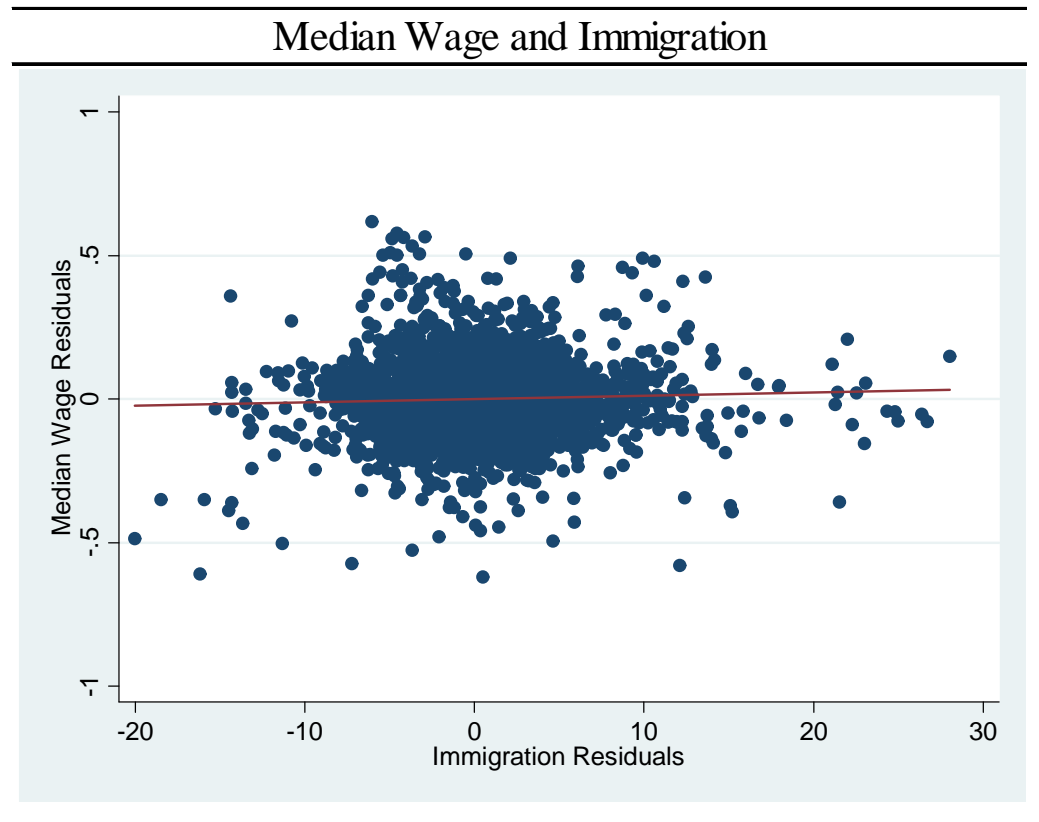

The residuals from regressing the ln median native wage on state, industry, and year fixed effects are plotted against the residuals from regressing immigration on state, industry, and year fixed effects. 
TABLE 1

Impact of Offshoring and Immigration on Native Wages

\begin{tabular}{|c|c|c|c|c|}
\hline & \multicolumn{2}{|c|}{ OLS } & \multicolumn{2}{|c|}{ IV } \\
\hline & $\ln ($ Wage 25 th $\%)$ & $\ln ($ Wage 75 th $\%)$ & $\ln ($ Wage 25 th $\%)$ & $\ln ($ Wage 75 th $\%)$ \\
\hline \multirow[t]{2}{*}{ L_Offshoring } & $0.044 * * *$ & $0.010^{* *}$ & $0.048 * * *$ & $0.016 * * *$ \\
\hline & [0.005] & [0.004] & {$[0.005]$} & {$[0.004]$} \\
\hline \multirow[t]{2}{*}{ L_Immigration } & $-0.001 * *$ & $-0.001 * *$ & $-0.002 * * *$ & $-0.001 * *$ \\
\hline & {$[0.000]$} & {$[0.000]$} & {$[0.001]$} & {$[0.000]$} \\
\hline \multirow[t]{2}{*}{ H_Offshoring } & $-0.039 * * *$ & $-0.025 * * *$ & $-0.063 * * *$ & $-0.050 * * *$ \\
\hline & [0.008] & [0.008] & {$[0.010]$} & [0.009] \\
\hline \multirow[t]{2}{*}{ H_Immigration } & $0.004 * * *$ & $0.003 * * *$ & -0.004 & $-0.004 *$ \\
\hline & {$[0.001]$} & {$[0.001]$} & [0.003] & [0.002] \\
\hline \multirow[t]{2}{*}{ Inshoring } & $0.027 * * *$ & $0.038 * * *$ & $0.048 * * *$ & $0.058 * * *$ \\
\hline & {$[0.008]$} & {$[0.008]$} & {$[0.010]$} & [0.009] \\
\hline \multirow[t]{2}{*}{ Age } & 0.002 & 0.003 & $0.005^{* *}$ & $0.005^{* * *} *$ \\
\hline & {$[0.002]$} & {$[0.002]$} & {$[0.002]$} & {$[0.002]$} \\
\hline \multirow[t]{2}{*}{ Education } & $0.198 * * *$ & $0.258 * * *$ & $0.215^{* * *}$ & $0.274 * * *$ \\
\hline & {$[0.008]$} & {$[0.008]$} & {$[0.010]$} & {$[0.010]$} \\
\hline \multirow[t]{2}{*}{ Male } & $0.009 * * *$ & $0.009 * * *$ & $0.009 * * *$ & $0.009 * * *$ \\
\hline & {$[0.000]$} & {$[0.000]$} & {$[0.000]$} & {$[0.000]$} \\
\hline \multirow[t]{2}{*}{ Black } & $0.001^{*}$ & $0.001 *$ & $0.001 * * *$ & $0.001 * * *$ \\
\hline & {$[0.000]$} & {$[0.000]$} & {$[0.000]$} & {$[0.000]$} \\
\hline \multirow[t]{2}{*}{ Asian } & 0.001 & 0.004 & $0.017 * * *$ & $0.020 * * *$ \\
\hline & {$[0.004]$} & {$[0.004]$} & {$[0.006]$} & {$[0.006]$} \\
\hline \multirow[t]{2}{*}{ Hispanic } & $-0.002^{*}$ & -0.001 & -0.001 & 0.000 \\
\hline & {$[0.001]$} & {$[0.001]$} & {$[0.001]$} & [0.001] \\
\hline \multirow[t]{2}{*}{ Married } & 0.001 & $0.002 * * *$ & 0.000 & $0.002 * * *$ \\
\hline & {$[0.001]$} & [0.001] & {$[0.001]$} & [0.001] \\
\hline \multirow[t]{2}{*}{ Single } & $-0.005 * * *$ & $-0.002 * * *$ & $-0.005 * * *$ & $-0.002 * * *$ \\
\hline & [0.001] & [0.001] & [0.001] & [0.001] \\
\hline Observations & 4,704 & 4,704 & 4,704 & 4,704 \\
\hline R-squared & 0.961 & 0.966 & 0.960 & 0.965 \\
\hline
\end{tabular}

Robust standard errors in brackets. * significant at 10\%; ** significant at 5\%; *** significant at 1\%. All regressions are weighted by the sample size and include year, state, industry, state*year, and industry*year fixed effects. 
TABLE 2

First Stage IV Regressions

\begin{tabular}{|c|c|c|c|c|}
\hline & L_Offshoring & L_Immigration & H_Offshoring & H_Immigration \\
\hline L_Offshoring IV & $\begin{array}{c}0.879 * * * \\
{[0.014]}\end{array}$ & $\begin{array}{c}-0.105 \\
{[0.106]}\end{array}$ & $\begin{array}{c}0.070 * * * \\
{[0.015]}\end{array}$ & $\begin{array}{c}0.253 * * * \\
{[0.080]}\end{array}$ \\
\hline L_Immigration IV & $\begin{array}{c}-0.001^{*} \\
{[0.001]}\end{array}$ & $\begin{array}{c}0.899 * * * \\
{[0.035]}\end{array}$ & $\begin{array}{c}-0.003 * * * \\
{[0.001]}\end{array}$ & $\begin{array}{c}-0.221 * * * \\
{[0.016]}\end{array}$ \\
\hline H_Offshoring IV & $\begin{array}{c}-0.053 * * \\
{[0.024]}\end{array}$ & $\begin{array}{c}-0.625^{*} * * \\
{[0.157]}\end{array}$ & $\begin{array}{c}0.547 * * * \\
{[0.016]}\end{array}$ & $\begin{array}{c}0.455^{* * *} * \\
{[0.108]}\end{array}$ \\
\hline H_Immigration IV & $\begin{array}{c}0.002 \\
{[0.002]}\end{array}$ & $\begin{array}{l}0.083^{*} \\
{[0.047]}\end{array}$ & $\begin{array}{c}0.002 \\
{[0.002]}\end{array}$ & $\begin{array}{c}0.461 * * * \\
{[0.034]}\end{array}$ \\
\hline $\begin{array}{l}\text { Observations } \\
\text { R-squared } \\
\text { F-Stat, Instruments }\end{array}$ & $\begin{array}{l}4,704 \\
1.000 \\
2315 \\
\end{array}$ & $\begin{array}{c}4,704 \\
0.958 \\
364 \\
\end{array}$ & $\begin{array}{c}4,704 \\
1.000 \\
566 \\
\end{array}$ & $\begin{array}{c}4,704 \\
0.941 \\
63 \\
\end{array}$ \\
\hline
\end{tabular}




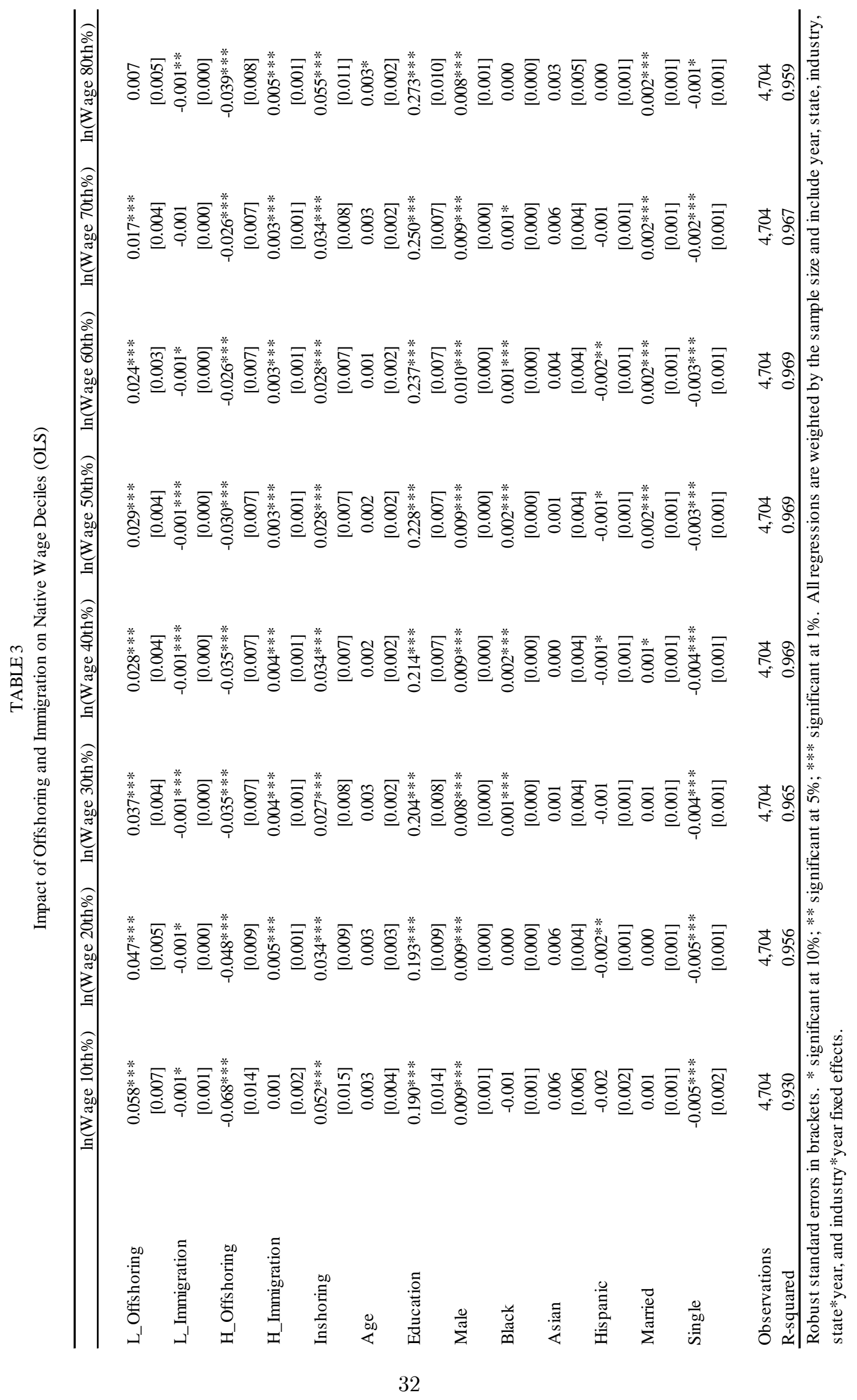




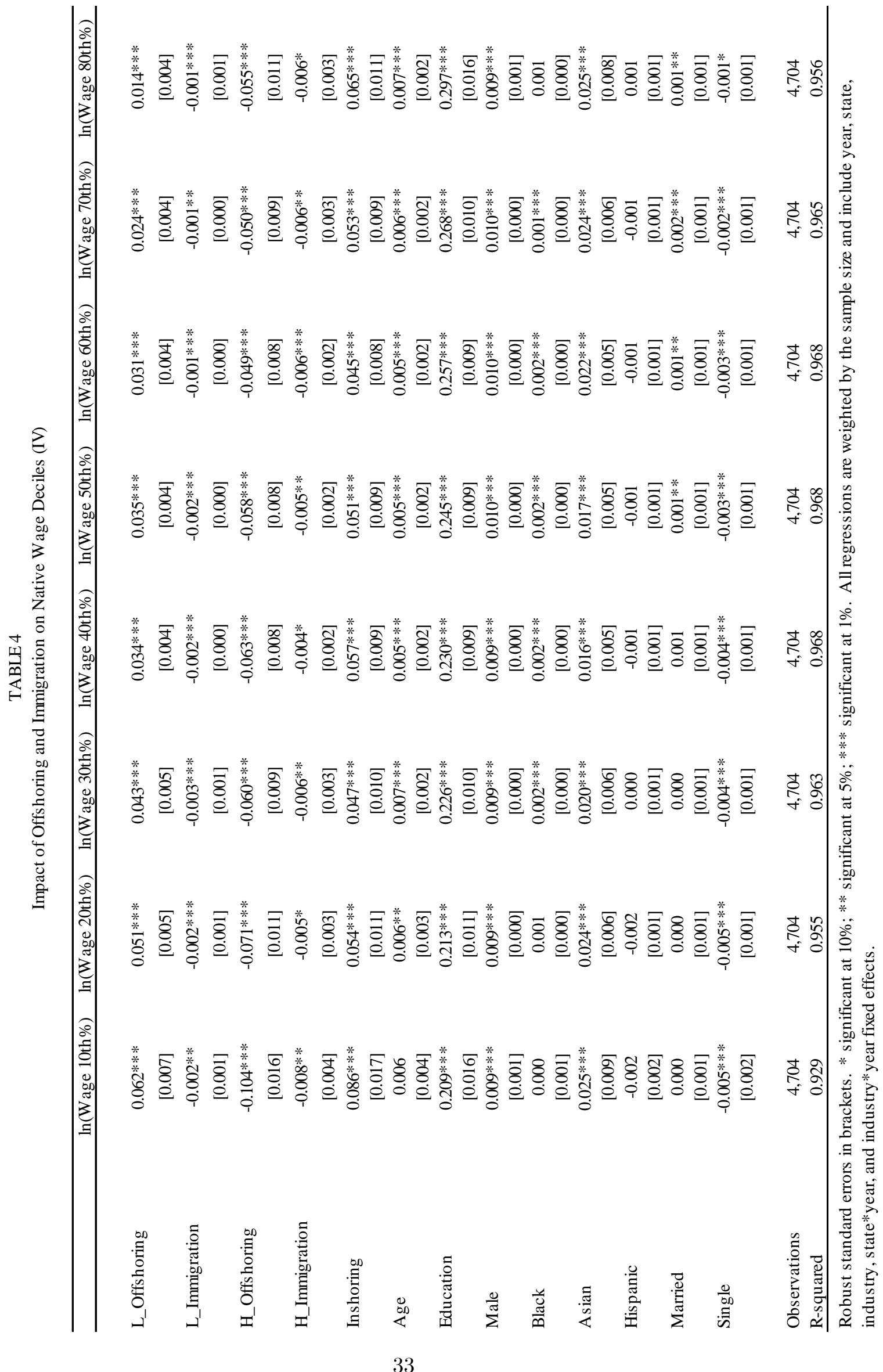


FIGURE 5

Impact of Offshoring and Immigration on Native Wage Deciles (IV)

(Coefficients and 95\% Confidence Intervals from Table 4)

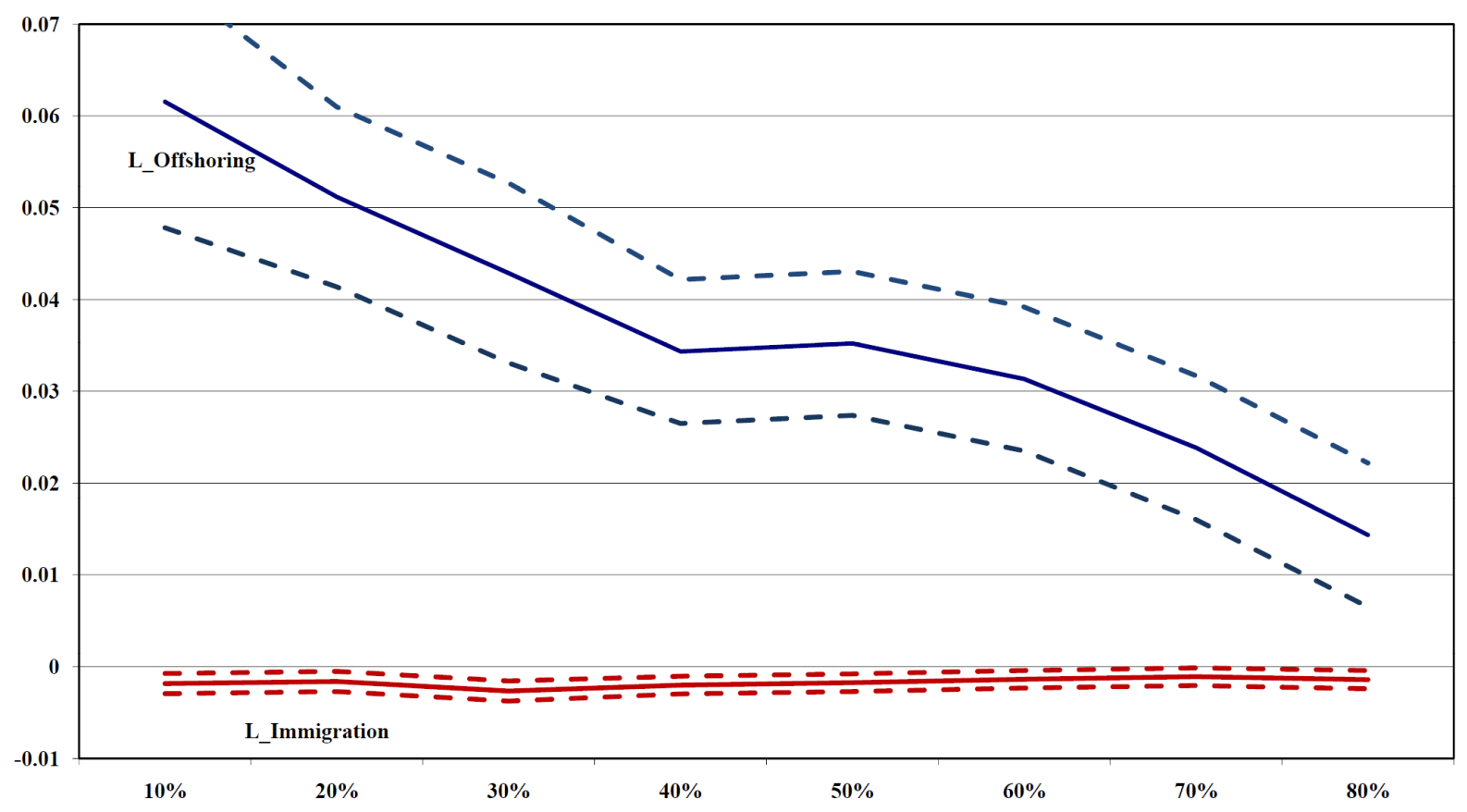




\section{A Model Appendix}

\section{A.1 Deriving Equation (7):}

Totally differentiating the ratio of (4) to (5) gives:

$\frac{d a_{L}}{a_{H}}\left(\frac{d w \Omega}{s}+\frac{d \Omega w}{s}-\frac{d s w \Omega}{s^{2}}\right)-\frac{a_{L} d a_{H}}{a_{H}^{2}}\left(\frac{d w \Omega}{s}+\frac{d \Omega w}{s}-\frac{d s w \Omega}{s^{2}}\right)=\frac{d L(1+I)}{H(1-J)}+\frac{d I L}{H(1-J)}-\frac{L(1+I) d H}{H^{2}(1-J)}+\frac{L(1+I) d J}{H(1-J)^{2}}$

or:

$\frac{a_{L}}{a_{H}}\left(\hat{a}_{L}-\hat{a}_{H}\right)\left(\frac{w \Omega}{s}\right)(\hat{w}+\hat{\Omega}-\hat{s})=\frac{L(1+I)}{H(1-J)}\left(\hat{L}+\frac{d I}{(1+I)}-\hat{H}+\frac{d J}{(1-J)}\right)$

The first terms on each side cancel following from the ratio of (4) to (5) and since the native factor supplies are fixed then $\hat{L}=\hat{H}=0$. Therefore:

$\left(\hat{a}_{H}-\hat{a}_{L}\right)\left(\frac{w \Omega}{s}\right)(\hat{s}-\hat{w}-\hat{\Omega})=\frac{d I}{(1+I)}+\frac{d J}{(1-J)}$

or:

(7) $\sigma(\hat{s}-\hat{w}-\hat{\Omega})=\frac{d I}{(1+I)}+\frac{d J}{(1-J)}$

where the elasticity of substitution is defined as:

$\sigma=\frac{d\left(\frac{a_{H}}{a_{L}}\right) /\left(\frac{a_{H}}{a_{L}}\right)}{d\left(\frac{w \Omega}{s}\right) /\left(\frac{w \Omega}{s}\right)}=\frac{\left(\hat{a}_{H}-\hat{a}_{L}\right)(w \Omega / s)(\hat{w}+\hat{\Omega}-\hat{s})}{(\hat{w}+\hat{\Omega}-\hat{s})}=\left(\hat{a}_{H}-\hat{a}_{L}\right)(w \Omega / s)$ 